Jurnal Instruksional, Volume 1, Nomor 2, April 2020131

ISSN: 2686-5645

\title{
PEMBELAJARAN BERBASIS RAMAH ANAK TAMAN KANAK-KANAK DI KECAMATAN BONTOTIRO KABUPATEN BULUKUMBA
}

\author{
Muhammad Yusri Bachtiar \\ Pendidikan Guru Pendidikan Anak Usia Dini, Universitas Negeri Makassar \\ email: muh.yusri.b@gmail.com
}

\begin{abstract}
The purpose of research on child-friendly learning in kindergarten as follows: 1) to determine the characteristics and needs in the field of child-friendly lerning models in kindergarten, 2) to find out the desgn and practicality of child-friendly learning models in kindergarten, 3) to determine the effectiveness of child-friendly learning models in kindergarten. The type of research used is Research and Development (R\&D) by following the Borg and Gall research steps. The location which is the place for researching $a$ child-friendly learning model is kindergarten, Bontotiro sub-district, Bulukumba regency with the characteristic of this model is the management of learning done by teachers is managing learning by applying child-friendly learning models in kindergarten in learning activities have been implemented well. Likewise the good. Anal activity in implementing a child-friendly learning model based on all indicators that exist in the child-friendly learning models is in the high cargoery
\end{abstract}

Keywords: friendly to early childhood, learning outcomes

\begin{abstract}
Abstrak
Tujuan penelitian pada pembelajaran ramah anak di Taman kanak-kanak sebagai berikut: 1) untuk mengetahui karakteristik dan kebutuhan lapangan model pembelajaran ramah anak di Taman kanakkanak. 2) untuk mengetahui desain dan kepraktisan model pembelajaran ramah anak di Taman Kanankanak, 3) untuk mengetahui keefektifan model pembelajaran ramah anak di Taman- Kanak. Jenis penelitian yang digunakan adalah Penelitian dan Pengembangan (R\&D) dengan mengikuti langkahlangkah penelitian Borg and Gall. Lokasi yang menjadi tempat penilitan model pembelajaran berbasis ramah anak adalah Di Taman Kanak-kanak, Kecamatan Bontotiro Kabupaten Bulukumba dengan ciri khas dari model ini adalah pengelolaan pembelajaran yang dilakukan oleh tenaga pendidik. Berdasarkan hasil penelitian dapat disimpulkan bahwa seluruh aktifitas guru dalam pengelolaan pembelajaran dengan menerapkan model pembelajaran ramah anak di Taman Kanak-kanak pada kegiatan pembelajaran sudah terlaksana dengan baik. Begitu juga respon guru terhadap model pembelajaran ramah anak berada pada kategori positif yaitu sangat baik. Aktifitas anal dalam pelaksanaan model pembelajaran ramah anak berdasarkan seluruh indikator yang ada pada model pembelajaran ramah anak berada pada kategori tinggi.
\end{abstract}

Kata kunci: ramah terhadap anak usia dini, hasil pembelajaran

\section{PENDAHULUAN}

Di Indonesia, sudah berkembang Sekolah Ramah Anak. Sekolah Ramah Anak adalah satuan pendidikan formal, nonformal dan informal yang aman, bersih dan sehat, peduli dan berbudaya lingkungan hidup, mampu menjamin, memenuhi, menghargai hak-hak anak dan perlindungan anak dari kekerasan, diskriminasi, dan perlakuan salah lainnya serta mendukung partisipasi anak terutama dalam perencanaan, kebajikan, pembelajaran, pengawasan, dan mekanisme pengaduan terkait pemenuhan hak dan perlindungan anak di pendidikan, (KPPA dan PA: 2016).

Sekolah yang secara sadar berupaya menjamin dan memenuhi hak-hak anak dalam setiap aspek kehidupan secara terencana dan bertanggung jawab. Prinsip utama adalah non diskriminasi kepentingan, hak hidup serta penghargaan terhadap anak. Sebagaimana dalam bunyi pasal 4 UU No. 23 Tahun 2002 tentang perlindungan anak, menyebutkan bahwa anak mempunyai hak 
untuk dapat hidup tumbuh, berkembang, dan berpartisipasi secara wajar sesuai harkat dan martabat kemanusiaan, serta mendapatkan perlindungan dari kekerasan dan diskriminasi. Sekolah Ramah Anak adalah sekolah yang terbuka melibatkan anak untuk berpartisipasi dalam segala kegiatan, kehidupan sosial,serta mendorong tumbuh kembang dan kesejahteraan anak (Yusi R Y: 2015).

Sekolah Ramah Anak adalah sekolah/madrasah yang aman, bersih, sehat, hijau, inklusif dan nyaman bagi perkembangan fisik, kognisi dan psikososial anak perempuan dan anak laki-laki termasuk anak yang memerlukan pendidikan khusus dan/atau pendidikan layanan khusus. Pengembangan program sekolah ramah anak ditujukan untuk memenuhi kebutuhan hak anak dan banyak di pengaruhi oleh lingkungan keluarga maupun lingkungan lainnya. Oong Komar, (2006: 68) mengatakan Meskipun anak dipegaruhi sangat besar oleh lingkungan keluarga, ia dapat menerima juga pengaruh dari lingkungan lainnya. Lingkungan pendidikan adalah tempat interaksi manusia dan kondisi alam dan kondisi sosial yang pada gilirannya dapat mengembangkan pengalaman pada diri anak yang bersangkutan.

Pengembangan program ramah anak juga telah dikembangkan oleh Balai Pengembangan Pendidikan Anak Usia Dini Non Formal dan Informal (BPPAUDNI) Regional III melalui Program Desa Ramah Anak (DRA) di Kecamatan Bontotiro Kabupaten Bulukumba. Liman dkk (2015 : 34) mengatakan program desa ramah anak melibatkan seluruh unsur yang terkaityang ada di desa tersebut dengan tujuan untuk pemenuhan hak-hak anak untuk pertumbuhan dan perkembangan. Hak-hak anak tersebut diantaranya untuk mendapatkan pendidikan yang layak, rasa aman dari tindak kekerasan dan pemenuhan akan gizi dan kesehatan anak.
Guru sebagai pendidik pada lembaga pendidikan anak usia dini memegang peran yang tidak kalah pentingnya dengan orang tua maupun masyarakat. Layanan pendidikan di sekolah sebagai tempat pendidikan yang pertama dan utama pada pendidikan anak usia dini bertanggungjawab untuk memenuhi kebutuhan untuk anak bertumbuh dan berkembang. Sehingga apapun yang dilakukan guru pada lingkungan sekolah akan berdampak pada kehidupan anak di masa yang akan datang. Kalau guru mampu memberikan layanan pendidikan yang baik, maka dengan sendirinya anak akan mendapatkan asupan pembelajaran yang baik juga, begitu juga sebaliknya.

Masalah kebutuhan perkembangan pada anak merupakan kebutuhan yang harus terpenuhi sesuai dengan perkembangan, maka masyarakat harus paham akan kebutuhan perkembangan anak usia dini sehingga dapat menangani masalah-masalah yang timbul, baik masalah pemenuhan kebutuhan perkembangan yang umum ataupun masalah kebutuhan perkembangan yang bersifat khusus. Tindak kekerasan terhadap anak usia dini yang masih sering terjadi, begitu pula dengan bentakan dari tenaga pendidik terhadap anak yang melakukan kesalahan akan berdampak buruk pada peningkatan pertumbuhan dan perkembangan anak. Disamping itu, masih banyak lembaga pendidikan yang belum menyediakan sarana dan prasarana pendidikan yang memadai, kurang perhatian pada kebersihan sekolah, dan lemahnya pengawasan terhadap anak ketika berada dalam sekolah.

Mengacu pada uraian di atas, maka dalam pemenuhan kebutuhan dasar anak untuk pertumbuhan dan berkembang perlu keterlibatan semua pihak, baik itu pemerintah, masyarakat, swasta terlebih lagi lembaga pendidikan. Pembelajaran Ramah Anak akan melahirkan generasi penerus 
yang memiliki perilaku tidak menyimpang dari aturan yang berlaku. Perilaku menyimpang misalnya adalah tindak kekerasan, korupsi, seks bebas, tindak kejahatan dan lain lain. Pembelajaran ramah anak diharapkan akan meningkatkan kognitif, bahasa, sosial emosional dan moral anak sehingga akan melahirkan anak yang berkepribadian ramah, sopan, santun, berkepribadian jujur, berkarakter baik, cerdas maupun cinta tanah air dan bangsa.

\section{KAJIAN LITERATUR}

Pembelajaran adalah upaya logis yang di dasarkan pada kebutuhan-kebutuhan belajar anak yang sangat bergantung pada pemahaman guru tentang hakikat anak sebagai peserta atau sasaran belajar. Dengan demikian, pembelajaran bersifat khas sesuai dengan karakteristik dan kebutuhan anak yang dilayaninya.

Sudarna (2014:16) mengatakan anak usia dini memiliki karakteristik seperti unik, egosentris, aktif dan energik, rasa ingin yang kuat dan antusias terhadap banyak hal, eksploratif dan berjiwa petualang, spontan, senang dan kaya akan fantasi, masih mudah frustasi, masih kurang mempertimbangkan dalam melakukan sesuatu, daya perhatian pendek, bergairah untuk belajar dan banyak belajar dari pengalaman dan semakin menunjukan minat terhadap teman.

Pelaksanaan pembelajaran untuk anak usia dini dilakukan berdasarkan prinsip dan pendekatan tertentu. Anita, (2011 : 67) mengemukakan prinsip-prinsip pembelajaran pada anak usia dini sebagai berikut:1) Berorientasi pada kebutuhan anak, 2) Belajar melalui bermain, 3) Kegiatan belajar mengembangkan dimensi kecerdasan secara terpadu, 4) Menggunakan pendekatan klasikal, kelompok dan individual, 5) Lingkungan kondusif, 6) Menggunakan berbagai model pembelajaran, 7) Mengembangkan keterampilan hidup dan hidup beragama, 8) Menggunakan media dan sumber belajar, 9) Pembelajaran berorientasi pada prinsip perkembangan dan belajar anak.

Peran aktif sekolah sebagai lembaga pendidikan adalah melayani kebutuhan anak didik khususnya yang ada di lingkungan pendidikan PAUD, peduli keadaan anak sebelum dan sesudah belajar, peduli kesehatan, gizi, dan membantu belajar hidup sehat, menghargai hak-hak anak dan kesetaraan gender, dan sebagai motivator, fasilitator sekaligus sahabat bagi anak

Ada beberapa prinsip yang dapat diterapkan untuk membangun pembelajaran ramah anak, diantaranya:

1. Guru dituntut untuk mampu menghadirkan dirinya sebagai sebuah media, tidak sekedar tempat yang menyenangkan bagi anak untuk belajar.

2. Dunia anak adalah "bermain". Dalam bermain itulah sesungguhnya anak melakukan proses belajar dan bekerja. Sekolah merupakan tempat bermain yang memperkenalkan persaingan yang sehat dalam sebuah proses belajarmengajar.

3. Guru perlu menciptakan ruang bagi anak untuk berbicara mengenai pembelajarannya. Tujuannya agar terjadi dialektika antara nilai yang diberikan oleh pendidikan kepada anak.

4. Lembaga pendidikan bukan merupakan dunia yang terpisah dari realitas keseharian anak dalam keluarga karena pencapaian cita-cita seorang anak tidak dapat terpisahan dari realitas keseharian.

Pembelajaran harus menciptakan suasana yang ramah agar anak merasa nyaman dan dapat mengekspresikan potensinya. Agar suasana konduksif tersebut tercipta, maka ada beberapa aspek yang perlu diperhatikan oleh guru, terutama: 1) tema pembelajaran yang sesuai; 2) lingkungan sekolah yang mendukung; dan 3) aspek sarana-prasarana bermain yang memadai.

Suyanto (2002: 39) mengatakan, kompetensi pada dasarnya merupakan 
deskripsi tentang apa yang dapat dilakukan seseorang dalam bekerja, serta apa wujud pekerjaan tersebut yang dapat dilihat. Untuk dapat melakukan pekerjaan, seseorang harus memiliki kemampuan dalam bentuk pengetahuan, sikap dan keterampilan yang relevan dengan bidang pekerjaannya.

Guru atau pendidik merupakan pekerjaan profesional seperti yang tertuang dalam UU No. 14 tahun 2005 tentang guru dan dosen dalam Bab II Pasal 2 dinyatakan bahwa guru mempunyai kedudukan sebagai tenaga profesional khususnya pada jalur formal untuk jenjang pendidikan anak usia dini. Kedudukan guru sebagai tenaga profesional berfungsi untuk meningkatkan martabat dan peran guru sebagai agen pembelajaran yang berfungsi meningkatkan mutu pendidikan formal dan nonformal.

Menurut Montessori (Jaipaul L Roopnarine \& james E. Johnson, 2011 : 399) sekolah dan guru harus memberikan kebebasan dalam lingkungan yang telah dipersiapkan jika ingin meraih tujuan . anak yang diberi kebebasan seperti ini dalam lingungan yang telah dipersiapkan akan berkembang sesuai dengan jadwal dan kecenderungan alamiah anak itu. Oleh karena itu tuga guru bukan untuk "mengajari" apa yang tidak dimiliki anak secara artifisial, namun sebaliknya menjadi pengamat yang teliti dalam perkembangan setiap anak, memberikan materi yang responsif pada pembelajar serta bimbingan dalam bentuk pengajaran, struktur yang konsisten, dan dorongan yang sesuai.

Peran pendidik dalam menciptakan pembelajaran ramah anak sangatlah menentukan, baik dari awal kedatangan peserta didik, saat pembelajaran maupun setelah pembelajaran. Adapun peran pendidik dalam memfasilitasi pembelajaran yang ramah anak pada lingkungan PAUD sebagai berikut:

\section{Sebelum pembelajaran:}

1. Guru datang lebih awal dari anak (30 menit sebelum masuk).

2. Guru menyiapkan peralatan untuk proses pembelajaran

3. Guru membersihkan tempat belajar.

4. Guru menyambut kedatangan anak senyum, salam, sapa dengan penuh semangat

5. Guru memulai belajar tepat waktu.

6. Guru mengkondisikan anak untuk siap belajar dengan ramah.

7. Guru mengkondisikan anak dan orang tua untuk siap berpisah sementara.

8. Guru berpenampilan bersih dan wangi.

Saat Pembelajaran :

1. Guru menggunakan bahasa yang mudah dipahami anak.

2. Guru menjadi teman bermain.

3. Guru menggunakan APE yang menarik.

4. Guru menjadi pendengar yang baik bagi anak.

5. Guru responsif terhadap perilaku anak.

6. Kegiatan/materi yang berpusat pada anak.

7. Guru terampil dalam memfasilitasi pembelajaran (misalnya terampil bernayanyi, menari, mendongeng).

8. Guru mampu menjadi pusat perhatian.

9. Guru menghargai karya anak.

10. Guru energik (aktif bergerak).

11. Guru menghibur dan memotivasi.

12. Guru mereview-merecalling.

Setelah pembelajaran :

1. Guru memberi salam.

2. Guru berpesan kepada anak (melalui janji pulang sekolah dan berpesan masuk di hari berikutnya).

3. Guru menghantar/memastikan anak sampai pada orang tua/keluarga.

4. Guru membereskan dan membersihkan ruangan.

5. Guru membuat Rencana Program Pembelajaran Harian (RPPH).

6. Guru melakukan evaluasi pembelajaran dan penilaian. 
Peran ini yang akan dijadikan patokan dalam pembelajaran ramah anak pada lingkungan pendidikan anak usia dini dan dapat menjadi pegangan setiap pendidik dalam menstimulasi tumbuh kembang anak usia dini. Dengan terciptanya pembelajaran yang ramah anak di lingkungan PAUD, maka anak-anak akan merasa aman, nyaman, senang dan dapat tumbuh dan berkembang dengan baik di usia emasnya.

Dalam pembelajaran anak usia dini selalu dikaitkan dengan standar tingkat pencapaian perkembangan anak yang mengacu pada Peraturan Menteri No. 137 Tahun 2014 tentang Standar Nasional Pendidikan Anak Usia Dini di sebutkan, standar tingkat pencapaian perkembangan anakterdiri dari Standar Isi, Standar Proses, Standar Penilaian, Standar Pendidik dan Tenaga Kependidikan, Standar Sarana dan Prasarana, Standar Pengelolaan, dan Standar Pembiayaan. Dan merupakan satu kesatuan yang tidak terpisahkan dalam pengelolaan dan penyelenggaraan pendidikan anak usia dini. Hal ini juga berlaku bagi pembelajaran ramah anak pada lingkungan pendidikan anak usia dini.

\section{METODE PENELITIAN}

Penelitian ini merupakan Penelitian dan pengembangan $(R$ and $D)$ yang menggunakan pendekatan Borg and Gall (dalam Sugiyono, 2013: 298) dengan langkah-langkah yang disedrhanakan dalam delapan langkah yaitu: 1) Potensi dan masalah, 2) Pengumpulan data, 3) Desain Produk, 4) Validasi Produk, 5) Revisi desain, 6) Uji coba produk, 7) Revisi produk dan 8) Ujicoba pemakaian. Subjek penelitian adalah guru dan anak TK Di Kecamatan Bontotiro Kabupaten Bulukumba. Fokus penelitian Pengembangan ini adalah model pembelajaran berbasis ramah anak pada lingkungan pendidikan anak usia dini.

Teknik analisis data akan digunakan teknik analisis data kualitatif dan analisis kuantitatif untuk melihat keterlaksanaan dan kepraktisan model pembelajaran berbasis ramah anak pada lingkungan PAUD.

\section{Analisis Kualitatif}

Pendekatan deskriptif dilakukan dimana tahap awal adalah dengan menghimpun data tentang pengamatan terhadap kondisi awal yang tampak di lokasi penelitian, antara lain: (a) kondisi proses pembelajaran yang ada di lokasi penelitian. Model-model pembelajaran yang dianggap menjadi masalah karena belum ada, atau ada tetapi tidak memenuhi kebutuhan pembelajaran, atau ada tetapi perlu diperbaiki. Pertimbangan ini sebagai dasar untuk merancang produk yang akan dikembangkan, (b) kondisi guru yang menggunakan modelmodel pembelajaran, (c) kondisi faktor pendukung lainnya seperti kompetensi guru, sarana dan prasarana yang tersedia serta kondisi fisik area belajar anak didik, dan (d) hasil evaluasi proses uji coba pengembangan model pembelajaran, berdasarkan temuan hasil maka dapat ditentukan perlu atau tidak perlu dilaksanakan perbaikan/revisi perangkat pembelajaran.

\section{Analisis Kuantitatif}

a. Uji Validitas Isi

Data hasil validasi para ahli (validator) yang meliputi model pembelajaran buku pedoman, program semester, rencana kegiatan mingguan (RKM), rencana kegiatan harian (RKH), lembar kegiatan aktifitas guru (LKAP), Lembar pengamatan pengelolaan pembelajaran (LPPP), Lembar kegiatan anak (LKA), dan Angket Respon Guru (ARG) dianalisis dengan mempertimbangkan masukan, komentar, dan saran-saran dari validator. Hasil analisis tersebut dijadikan sebagai pedoman untuk merevisi model pembelajaran yang telah disusun. 
b. Uji Validitas Empirik

Uji validitas empirik dilakukan untuk menguji coba produk secara terbatas sesuai penerapan model pembelajaran berbasis ramah anak pada lingkungan PAUD bagi anak Taman Kanak-kanak kelompok B. Hal ini dilakukan untuk mendapatkan informasi apakah model pembelajaran berbasis ramah anak pada lingkungan PAUD bagi anak Taman Kanak-kanak kelompok B ini telah memenuhi kriteria kepraktisan (keterlaksanaan) dan kefektifan produk.

\section{HASIL DAN PEMBAHASAN}

Tahapan awal dalam model Bord and Gall adalah tahap analisis. Tahap analisis yang dilakukan dalam penelitian ini untuk mendapatkan gambaran umum penerapan model pembelajaran yang telah digunakan selama ini pada TK di kecamatan Bontotiro kabupaten bulukumba khususnya pada anak usia 5-6 tahun.

\section{Gambaran Studi Pendahuluan \\ 1. Hasil Telaah Teoritis}

Tahap awal melakukan telaah teoritis/mengkaji secara mendalam tentang prosedur model pembelajaran ramah anak pada lingkungan PAUD, dengan pengkajian terhadap pembelajaran anak usia dini, pembelajaran ramah anak serta lingkungan pendidikan anak usia dini disamping itu juga melakukan pengamatan awal tentang prosedur pembelajaran di Taman KanakKanak Kabupaten Bulukumba. Dari kajian tersebut diperoleh data bahwa pembelajaran ramah anak pada lingkungan PAUD sudah terlaksana namun belum terprogram secara jelas. Peran tenaga pendidik pada pembelajaran ramah anak belum terprogram, dan indikator-indikator yang diharapkan berkembang pada anak usia dini juga belum bisa terukur.

\section{Hasil Telaah Empirik}

Peneliti telah mengkaji secara empirik pengembangan model pembelajaran ramah anak pada lingkungan PAUD di TK Kecematan Bontotiro Kabupaten Bulukumba sebagai berikut:

\section{a. Analisis Peran Guru}

1) Analisis ini, peneliti mengamati peran guru dalam mengelola pembelajaran dalam menerapkan model pembelajaran ramah anak pada lingkungan PAUD yang akan dikembangkan, sehingga peneliti memperoleh informasi dan pengetahuan mengenai pemahaman guru yang masih kurang tentang pembelajaran ramah anak, kurang memahami tentang peran guru dalam pembelajaran ramah anak, serta pemahaman guru terhadap indikator-indikator dalam pembelajaran ramah anak pada lingkungan PAUD.

2) Melakukan analisis awal tentang kemampuan guru dalam melakukan persiapan pembelajaran, melakukan penyambutan anak, menentukan intesitas bermain, menata lingkungan main, kemampuan guru dalam berinteraksi dengan anak didik dalam pembelajaran, dan kemampuan guru dalam mengajak anak untuk beres-beres dan recalling. Hasil analisis ini sangat membantu dalam membuat model pembelajaran ramah anak pada lingkungan PAUD.

\section{b. Analisis Peserta Didik}

Analisis ini bertujuan untuk mendapatkan gambaran mengenai karakteristik anak Di Kecamatan Bontotiro Kabupaten Bulukumba Informasi yang diperoleh pada anak didik kelompok B antara lain adalah masih adanya perlakuan siswa yang memukul temannya walaupun tanpa sebab maupun persoalan sepele, anak belum memiliki sikap toleransi yang tinggi, belum memiliki sikap peduli lingkungan dan belum memperihatkan sikap setia kawan, sehingga tidak 
tercipta sikap bangga terhadap sekolah. Oleh karena itu perlu model pembelajaran ramah anak pada lingkungan PAUD membantu guru dalam pembelajaran di sekolah.

\section{c. Analisis Materi Pembelajaran}

Peneliti mengidentifikasi isi/materi pembelajaran yang akan dipelajari oleh anak didik adalah materi pembelajaran pada semester dua Tahun Pelajaran 2016-2017, sesuai dengan Keputusan Menteri Nomor 137 tahun 2014 tentang Standar PAUD dan Nomor 146 tahun 2014 tentang Kurikulum 2013 PAUD. Tema yang dikembangkan antara lain tema diri sendiri, lingkungan dan transportasi. Tema yang dikembangkan ini diharapakan agar anak didik memperoleh pengalaman belajar yang disesuaikan dengan tingkat pencapaian perkembangan.

\section{d. Analisis Kebutuhan Pengembangan}

Analisis kebutuhan pengembangan dimaksudkan untuk melihat kebutuhan dasar yang diperlukan untuk mengembangkan model pembelajaran ramah anak pada lingkungan PAUD. Hasil identifikasi kebutuhan terhadap 8 orang pendidik dan tenaga kependidikan PAUD di Kabupaten Bulukumba dijadikan pertimbangan dalam merancang model hipotetik, antara lain; (a) perlu adanya refrensi model pembelajaran ramah anak pada lingkungan PAUD yang memudahkan guru dalam mengimplementasikan tiap indikator yang ingin dicapai, (b) model yang dikembangkan hendaknya diuraikan secara jelas, dan (c) guru melaksanakan model tersebut dengan baik.

Berdasarkan hasil analisis tersebut, maka dipandang penting untuk melaksanakan model pembelajaran ramah anak pada lingkungan PAUD. Penunjang keterlaksanaan model ini maka perlu dibuat buku panduan sebagai pegangan guru dalam melaksanakan model, program semester, rencana program pembelajaran mingguan, dan rencana program pembelajaran harian.

\section{Gambaran Hipotetik Model}

Hasil analisa menunjukkan bahwa perlu untuk menerapkan model pembelajaran ramah anak pada lingkungan PAUD sebagai salah satu bahan referensi guru untuk mencapai tumbuh kembang anak yang maksimal. Kajian teoritis mengungkapkan bahwa pembelajaran yang ramah terhadap anak akan mampu menjadikan anak yang memiliki sikap anti kekerasan, memiliki sikap toleransi yang tinggi, memiliki sikap peduli lingkungan, memiliki sikap setia kawan, dan memiliki sikap bangga terhadap sekolah.

Rancangan model hipotetik pengembangan model pembelajaran ramah anak pada lingkungan PAUD ini disusun dalam buku panduan sebagai pegangan guru, program semester, rencana pelaksanaan pembelajaran mingguan, dan rencana pelaksanaan pembelajaran harian. Validasi empirik dilakukan dengan menggunakan instrument penilaian yang terdiri atas: 1) Lembar Pengamatan Keterleksanaan Model, 2) Lembar pengamatan Pengelolalaan Pembelajaaran, dan 3) Lembar Pengamatan Aktivitas Anak.

\section{Hasil Pengembangan Model}

Hasil pengembangan model pembelajaran kegiatan sebelum pembelajaran, saat pembelajaran dan sesudah pembelajaran yang telah dirancang sebelumnya, selanjutnya dilakukan validasi isi (content validity) dan validasi empirik (empirical validity.

\section{Validasi Isi}

Validasi isi dilakukan dua (2) orang ahli/pakar merupakan kegiatan penilaian para ahli terhadap model pembelajaran awal yang telah dibuat. Para ahli diminta 
untuk memvalidasi semua rangkaian model yang telah dibuat pada tahap sebelumnya. Saran dari para ahli digunakan sebagai acuan dalam melakukan revisi terhadap model pembelajaran yang telah dibuat dalam bentuk buku panduan. Adapun Hasil penilaian validator terhadap produk model pembelajaran ini yang meliputi: Buku panduan model pembelajaran ramah anak pada lingkungan PAUD, Program Semester, Rencana Pelaksanaan Pembelajaran Mingguan (RPPM), Rencana Pelaksanaan Pembelajaran Harian (RPPH), Lembar Pengamatan Keterlaksanaan Model (LPKM), Lembar Pengamatan Pengelolaan Pembelajaran (LPPP), Lembar Pengamatan Kegiatan Anak (LPKA), dan Angket Respon Guru (ARG) dapat disimpulkan dengan kategori semuanya valid.

\section{Validasi Empirik}

Validasi empirik pada pengembagan model pembelajaran berbasis ramah anak dapat dilakukan dengan mengamati kemampuan guru mengelola pembelajaran dan kemampuan guru menggunakan model pembelajaran. Berdasarkan hasil analisi empirik maka dapat disimpulkan bahwa respon guru terhadap model pembelajaran ramah anak pada lingkungan PAUD pada anak TK berada pada kategori positif yaitu "baik/setuju". Ini terlihat dari hasil analisis data yang menyebutkan bahwa dari empat responden yang memberikan respon dengan 20 item pernyataan seperti terlampir, terdapat $22.22 \%$ dari pernyataan responden yang mengatakan bahwa model pembelajaran ramah anak pada lingkungan PAUD dapat memotivasi guru dan anak dalam pembelajaran, dan $2.78 \%$ dari responden malah menyatakan sangat setuju kalau model pembelajaran ramah anak pada lingkungan PAUD ini membuat mereka lebih aktif dalam proses belajar mengajar di taman kanak-kanak sedangkan $36.11 \%$ menyatakan setuju kalau model ini membuat mereka lebih aktif. Selain itu, guru juga memberikan respon positif kalau model pembelajaran ramah anak pada lingkungan PAUD sudah efektif diterapkan di taman kanakkanak dengan $27.78 \%$ mengaku setuju. Sementara $4.17 \%$ memberikan trespon sangat setuju kalau model pembelajaran ramah anak pada lingkungan PAUD mampu meningkatkan motivasi belajar, dan 6.94 memberi respon setuju. Sehingga dari seluruh item pengamatan respon guru terhadap model pembelajaran ramah anak pada lingkungan PAUD dapat di tarik total persentasenya yakni untuk respon guru yang sangat setuju sebanyak $6.94 \%$, respon guru pada model pembelajaran ramah anak pada lingkungan PAUD dilihat dari kategori setuju sebanyak $93.06 \%$ dan untuk pernyataan tidak setuju dan sangat tidak setuju pada respon guru dilihat pada seluruh item pernyataan pada model pembelajaran ramah anak pada lingkungan PAUD tidak ada atau 0.

Dari uraian di atas dapat disimpulkan kalau respon guru terhadap model pembelajaran ramah anak pada lingkungan PAUD berada pada kategori setuju dengan jumlah persentase $93.06 \%$, dimana kalau dilihat dari kriteria respon guru pada Bab III halaman 90 yang mengatakan apabila penilaian guru $\geq 90 \%$, maka respon guru tersebut positif "baik". Hal ini menandakan kalau model pembelajaran ramah anak pada lingkungan PAUD dapat dikatakan praktis.

Pada model pembelajaran efektif apabila memenuhi kriteria-kriteria tersebut dibawah ini yaitu adalah (1) ketercapaian keaktifan dilihat dari indikator aktifitas anak mengikuti tercapai yaitu minimal $70 \%$, (2) aktivitas anak didik selama kegiatan belajar memenuhi kriteria ideal apabila nilai AS 
minimal berada dalam kategori tinggi ( $50 \leq$ AS $<75$ ).

Model pembelajaran ramah anak pada lingkungan PAUD adalah model pembelajaran yang dilakukan guru dalam lingkungan pendidikan anak usia dini dengan baik hati dan menarik budi bahasanya, manis tutur kata dan sikapnya, dan menyenangkan bagi anak didik dalam upaya memenuhi hak-hak anak. Hal ini membantu untuk meningkatkan pertumbuhan dan perkembangan anak sesuai dengan indikator yang diharapkan. Keefektifan model pembelajaran ramah anak dapat dilihat dari ketercapaian dalam mewadahi serta menumbuh kembangkan berbagai kemampuan fisik, kognitif, bahasa, sosio emosional dan spiritual.

Secara empirik, model pembelajaran ramah anak ini juga telah dibuktikan mampu dan sukses untuk memicu akselerasi dan menaikkan kapasitas daya ingat (memori) peserta didik (enhance learning and increase long-term memory capabilities of learners) untuk jangka waktu yang lebih panjang.

Berdasarkan hasil penelitian yang diperoleh pada model pembelajaran ramah anak Taman Kanak-kanak telah dilaksanakan pada satuan pendidikan anak usia dini dapat bahwa tujuan penelitian ini adalah untuk mendeskripsikan karakteristik dan kebutuhan lapangan berkaitan dengan rencana pengembangan model pembelajaran Berbasis ramah anak dalam upaya mengembangkan potensi yang ada pada diri anak. Dari hasil pengamatan peneliti pada saat kunjungan dibeberapa satuan pendidikan anak usia dini yang ada di daerah kabupaten/kota khususnya di Provinsi Sulawesi Selatan. selain pada saat studi lapangan menunjukkan bahwa, proses pembelajaran anak usia dini di Lembaga PAUD, khususnya di taman kanak-kanak, peneliti melihat masih banyak satuan PAUD yang melakukan pembelajaran dengan hukuman fisik dan fsikis pada saat pembelajaran dan bahkan setelah pembelajaran. Hal ini akibat perbedaan penafsiran oleh guru taman kanak-kanak dalam mendefinisikan dan menerapkan pendekatan pembelajaran anak usia dini. Sementara pembelajaran yang ideal menurut peneliti di satuan PAUD taman kanakkanak, yaitu pembelajaran yang berpusat pada anak, sehingga guru hanya sebagai motivator dalam pembelajaran di lingkungan PAUD.

Sehingga idealnya seorang pendidik PAUD di Taman Kanak-kanak perlu memahami hal yang sangat dibutuhkan dalam pembelajaran anak dan juga sangat perlu tahu bagaimanakah pendekatan yang dilakukan dalam menghadapi anak dalam proses pembelajaran di lingkungan PAUD. Tegasnya, Pembelajaran ramah anak merupakan sebuah pembelajaran yang menekankan agar seorang guru lebih kreatif. Kreativitas yang dimiliki seorang guru ini sebagai salah satu solusi penerapan dan pengembangan pembelajaran ramah anak di satuan PAUD, yang sampai saat ini belum semua dapat diimplementasikan secara keseluruhan oleh satuan PAUD. Guru juga harus lebih aktif dan mampu memanfaatkan perkembangan ilmu pengetahuan dan teknologi untuk mengembangkan model pembelajaran serta memanfaatkan media dan lingkungan sehingga mampu mengaplikasikan pembelajaran ramah anak dilingkungan PAUD.

Satuan PAUD Taman Kanak-kanak saat ini, belum semuanya memiliki sarana pembelajaran sesuai standar yang berlaku saat ini. Kenyataan di lapangan menunjukkan bahwa masih banyak Taman Kanak-kanak yang sarana pembelajarannya masih jauh dari harapan. Jika dibandingkan dengan kondisi TK tempat kami melaksanakan penelitian sarana prasarana di dalam ruang belajar (indoor) sudah sangat baik, hanya ruang belajar luar (outdoor) yang menurut kami masih sempit untuk area 
bermain anak, disamping ada beberapa sarana bermain yang tidak layak untuk digunakan karena dapat membahayakan anak-anak yang menggunakannya.

Temuan khusus dalam pelaksanaan ujicoba model ini terkait dengan penyusunan dan implementasi model pembelajaran ramah anak pada lingkungan PAUD di TK Kecamatan Bontotiro Kabupaten Bulukumba terdiri atas beberapa tahapan yaitu:

\section{Tahap Perencanaan}

Dalam hal penyusunan rencana pembelajaran ramah anak pada lingkungan PAUD oleh peneliti yang akan diterapkan guru dalam pelaksanaan model pembelajaran yang terdiri dari:

a. Penyusunan jaringan tema yang melingkupi beberapa tingkat pencapaian perkembangan (TPP) dan indikator yang dikembangkan dalam Rencana Pelaksanaan Pembelajaran Harian ada, dan penilaian menurut pengamat sudah baik dengan persentase $100 \%$.

b. Tujuan pembelajaran yang akan dicapai pada setiap kegiatan pembelajaran dalam Rencana Pelaksanaan Pembelajaran Harian ada, dan penilaian menurut pengamat sudah baik dengan persentase $100 \%$.

c. Kegiatan pembelajaran yang ramah anak dalam dalam Rencana Pelaksanaan Pembelajaran Harian ada, dan penilaian menurut pengamat sudah baik dengan persentase $80 \%$,

d. Pengalaman belajar yang bermakna untuk membangun sikap dan perilaku positif, penguasaan konsep, berpikir tingkat tinggi, kemampuan menyelesaikan masalah, inkuiri, kreativitas, dan pribadi reflektif dalam Rencana Pelaksanaan Pembelajaran Harian, sudah dilaksanakan, dan penilaian menurut pengamat sudah cukup baik dengan persentase $70 \%$.

\section{Tahap Pelaksanaan}

Dalam tahapan ini oleh guru PAUD melaksanakan model pembelajaran ramah anak pada lingkungan PAUD bagi anak di TK Kecamatan Bontotiro Kabupaten Bulukumba yaitu:

a. Mengintegrasikan tema dengan kurikulum yang yang telah disusun, dengan mengedepankan dimensi : Sikap, Pengetahuan dan Keterampilan, sudah dilaksanakan dan penilaian menurut pengamat pelaksanaannya baik dengan persentase $60 \%$.

b. Mengembangkan ide-ide kreatif dalam pemilihan metode pembelajaran. Termasuk di dalamnya menemukan kegiatan alternatif apabila kondisi yang terjadi kurang sesuai dengan perencanaan. sudah dilaksanakan dan penilaian menurut pengamat pelaksanaannya baik dengan persentase $80 \%$.

c. Memilih beragam metode pembelajaran yang akan dikembangkan (misalnya bermain peran, mengamati, bertanya, bercerita, bernyanyi, menggambar, dan sebagainya). sudah dilaksanakan dan penilaian menurut pengamat pelaksanaannya cukup baik dengan persentase $70 \%$.

d. Mengembangkan keterampilan. pembelajaran Aktif, Inovatif, Kreatif, Efektif, dan Menyenangkan (PAIKEM), sudah dilaksanakan dan penilaian menurut pengamat pelaksanaannya baik dengan persentase $60 \%$.

e. Mengembangkan keterampilan bertanya yang berorientasi pada kemampuan berpikir tingkat tinggi, sudah dilaksanakan dan penilaian menurut pengamat pelaksanaannya cukup baik dengan persentase $50 \%$. 
f. Mengembangkan keterampilan membuka dan menutup pembelajaran, dan keterampilan mengelola kelas dan pajangan kelas, sudah dilaksanakan dan penilaian menurut pengamat pelaksanaannya baik dengan persentase $80 \%$.

g. Menggunakan media atau sumber belajar alternatif yang tersedia di lingkungan sekolah, sudah dilaksanakan dan penilaian menurut pengamat pelaksanaannya cukup baik dengan persentase $70 \%$.

\section{Tahap Evaluasi}

Dalam tahapan ini oleh guru PAUD melaksanakan evaluasi pelaksanaan model pembelajaran ramah anak bagi anak di kelompok TK Kecamatan Bontotiro Kabupaten Bulukumba yaitu: membuat catatan refleksi setelah pembelajaran selesai, sebagai bahan untuk melakukan perbaikan pada proses pembelajaran selanjutnya. Misalnya faktor-faktor yang menyebabkan pembelajaran berlangsung dengan baik, kendala-kendala yang dihadapi, dan ideide kreatif untuk pengembangan lebih lanjut. Pelaksanaan evaluasi ini sudah dilaksanakan dan penilaian menurut pengamat pelaksanaannya cukup baik dengan persentase $40 \%$.

\section{KESIMPULAN}

Berdasarkan

hasil penelitian pembelajaran ramah anak pada lingkungan PAUD di kelompok B Taman Kanak-kanak di kecamatan bontotiro kabupaten bulukumba, maka dapat ditarik kesimpulan sebagai berikut:

1. Model pembelajaran berbasis ramah anak memiliki nilai-nilai yang konsisten sesuai dengan kebutuhan pembelajaran anak pada lingkungan PAUD. Model inimenekankan pada kemampuan guru dalam mengelola pemebelajaran di lembaga PAUD. Kemampuan tersebut, yakni kemampuan guru dalam melakukan persiapan pembelajaran, saat melakukan penyambutan terhadap anak, menentukan densitas main, menata lingkungan main, kemampuan guru dalam berinteraksi dengan anak didik dalam proses pembelajaran, dan kemampuan guru dalam mengajak anak untuk beres-beres dan recalling.

2. Aktifitas guru dalam model pembelajaran ramah anak pada lingkungan pendidikan anak usia dini yang telah diujicobakan terlaksana dengan baik. Begitu juga keterlaksanaan model pada saat ujicoba berada pada kategori baik. Hal yang sama juga ditemukan pada respon guru terhadap pembelajaran ramah anak pada lingkungan PAUD bagi anak taman kanak-kanak kelompok B berada pada kategori positif yaitu "sangat baik" atau sangat setuju.

3. Keefektifan model pembelajaran ramah anak pada lingkungan pendidikan anak usia dini pada pembelajaran ramah anak pada lingkungan PAUD bagi anak taman kanak-kanak di kecamatan bontotiro kabupaten bulukumba berdasarkan seluruh indikator berada pada kategori "tinggi".

\section{REFERENSI}

Anita Yus, 2012. Model Pendidikan Anak Usia Dini, Jakarta:Kencana PrenadaMedia Group.

Asmawati L, 2014. Perencanaan Pembelajaran $P A U D$, Bandung. Remaja Rosdakarya.

Asnawir, Usman, 2002. Media Pembelajaran, Jakarta: Raja Grafindo.

Gardner H, 2003, Multiple Intelegences. Kecerdasan Majemuk, Teori dan Praktek, Jakarta: Interaksara. 
Hibama S Rahman, 2002, Konsep Dasar Pendidikan Anak Usia Dini, Yokyakatya, Galah.

Komar Oong, 2006. Filsafat Pendidikan Nonformal, Bandung: Pustaka Setia.

KPP dan PA, 2016. Makalah Kebijakan Sekolah Ramah Anak. Pelatihan Sekolah Ramah Anak Bagi Guru-Guru Se Kota Makassar, Makassar, BP-PAUD dan DIKMAS.

Liman dkk, 2015. Model Desa Ramah Anak. Makassar. Balai Pengembangan Pendidikan Anak Usia Dini Nonformal dan Informal Regional III,Depdiknas.

Mariyana R dkk, 2009. Pengelolaan Lingkungan Belajar, Jakarta: Kencana Prenada Media Group.

Menteri Pendidikan Nasional. 2014. Standar Nasional Pendidikan Anak Usia Dini, Jakarta: Balai Pustaka.

Mulyasa H.E.2012. Manajemen PAUD, Bandung : PT Remaja Rosdakarya

Putra N, 2012. Researh and Development. Penelitian dan Pengembangan: Suatu Pengantar, Jakarta: RajaGrafindo Persada.
Roopnarine J.L dkk. 2011. Pendidikan Anak Usia Dini Dalam Berbagai Pendekatan, Jakarta. Kencana Pranada Media Group.

Santrock J. W. 2013. Psikologi Pendidikan, Edisi Kedua, Jakarta. Kencana Prenada Media Group.

Sudarna. 2014. Pendidikan Anak Usia Dini Berkarakter. Melejitkan Kepribadian anak Secara Utuh (Kecerdasan Emosi, Spirit, dan Sosial), Yokyakarta. Genius Publisher.

Sugiyono. 2013. Metode Penelitian Kuantitatif dan Researh and Development, Bandung: Alfabeta.

Suyanto S. 2005. Dasar-Dasar Pendidikan Anak Usia Dini, Yokyakarta: Hikayat.

Yulianti D. 2010. Pendidikan Anak Usia Dini, Jakarta: DIVA. Press.

Yusi RY. 2015. Artikel Pengembangan Model Sekolah Ramah Anak (di Kota Bandung), Implementasi Pendekatan Restorative Justice Dalam Menangani Peserta Dididk Yang Melakukan Pelanggaran Aturan Sekola, Bandung. 